\title{
Integration of Brassica Cover Crop with Host Resistance and Azoxystrobin for Management of Rice Sheath Blight
}

Maxwell Handiseni, AgriLife Research and Extension Center, Texas A\&M University System, Beaumont 77713; Young-Ki Jo, Department of Plant Pathology and Microbiology, Texas A\&M University, College Station 77843; and Xin-Gen (Shane) Zhou, AgriLife Research and Extension Center, Texas A\&M University System, Beaumont

\begin{abstract}
Handiseni, M., Jo, Y.-K., and Zhou, X. G. 2015. Integration of Brassica cover crop with host resistance and azoxystrobin for management of rice sheath blight. Plant Dis. 99:883-885.

Sheath blight caused by Rhizoctonia solani is the most important rice disease that can cause significant losses in grain yield and quality in the southern United States. Current management options for sheath blight primarily consist of fungicides, tolerant cultivars, and cultural practices. These options are not always very effective. Brassica plants have been used for soil fumigation to manage a variety of different soilborne pathogens. In this field study, the efficacy of a Brassica juncea cover crop integrated with use of a tolerant rice cultivar and fungicide application was evaluated in 2011,2012 , and 2013 . The $B$. juncea cover crop significantly

lowered sheath blight severity in all 3 years and led to a significantly higher grain yield in 2013 as compared with the fallow control. 'Presidio' rice had lower sheath blight severity and higher yield than 'Cocodrie' in 2012 and 2013. Fungicide applications with azoxystrobin at the label rate ( $0.16 \mathrm{~kg}$ a.i.//ha) or half the label rate $(0.08 \mathrm{~kg}$ a.i./ha) significantly reduced sheath blight severity in all 3 years, resulting in a yield increase in 2 of the 3 years. $B$. juncea along with use of a tolerant rice cultivar and half the label rate of azoxystrobin can be an effective approach for management of sheath blight in rice.
\end{abstract}

Rice (Oryza sativa L.) is one of the most important food crops in fighting against global hunger. Over half of the world's population depend on rice as their staple diet. The United States rice industry produced more than 958,000 tons from more than 997,000 ha in 2013 (25). One of the major diseases limiting rice production in the southern United States is sheath blight, caused by Rhizoctonia solani Kühn AG1-1A (teleomorph Thanatephorus cucumeris (A. B. Frank) Donk) (3). Sheath blight can cause as much as $50 \%$ yield loss and significant loss in grain quality (4). The pathogen overwinters in infected plant tissue as sclerotia and mycelium, which serve as the primary inoculum and may survive in the soil for up to 2 years (14). It has a wide host range comprising both monocots and dicots (14), including soybean. Many rice farmers in the United States rotate rice and soybean, both of which serve as hosts for $R$. solani. There has been an increase in sheath blight incidence and severity, and this has been attributed to modern rice production practices such as large-scale monoculture, use of semidwarf cultivars, high nitrogen fertilization, and high plant populations (3). There are no commercial rice cultivars highly resistant to sheath blight. Therefore, sheath blight management practices have been focused on the use of tolerant varieties, optimized nitrogen fertility, proper seeding rates, and inoculum-reducing practices such as rotation, cultivation, and sanitation $(3,4,13)$. Given the application of these cultural disease management practices, rice farmers in the United States still heavily rely on synthetic fungicides. Intensified and largescale use of fungicides can result in negative impacts on the environment $(2,5)$.

Biofumigation using Brassica plant materials has grown as an environmentally friendly approach to plant pest management (18). The pesticidal effect of the Brassica plant is based on the production of toxic and volatile isothiocyanates upon hydrolysis by myrosinases. Isothiocyanates have biocidal activity toward numerous plant pests (1), parasitic nematodes $(10,11,24)$, and plant-pathogenic fungi and oomycetes $(17,18)$. Efficacy of Brassica plant tissue has been reported

Corresponding author: X.-G. Zhou; E-mail: xzhou@ aesrg.tamu.edu

Accepted for publication 21 November 2014.

http://dx.doi.org/10.1094/PDIS-08-14-0845-RE

(C) 2015 The American Phytopathological Society against Verticillium wilt (Verticillium dahlia) on cauliflower (Brassica oleracea var. botrytis) (24); Sclerotinia sclerotiorum (22), V. dahliae (21), and take-all (Gaeumannomyces graminis) on wheat (Triticum aestivum) (12); and Sclerotinia drop (Sclerotinia minor) on lettuce (Lactuca sativa) (8). Techniques such as use of Brassica seed meals and macerated Brassica plant tissue have been developed to achieve soil fumigation. Biofumigation was reported to be effective for suppressing $R$. solani infection in apple (Malus sylvestris (L.) Mill.) cropping systems (18). B. juncea cover cropping and subsequent plant tissue incorporation into the soil prior to rice planting may be of great merit as a sustainable management option for control of sheath blight but has not, to our knowledge, been evaluated in the field. The objective of this study was to evaluate efficacy of integrating a $B$. juncea cover crop with the use of a tolerant cultivar and application of azoxystrobin on rice sheath blight.

\section{Materials and Methods}

Experimental location and design. Experiments were conducted from 2011 to 2013 in rice fields having League type soil (3\% sand, $32 \%$ silt, and $64 \%$ clay) at the Texas A\&M AgriLife Research and Extension Center in Beaumont. The experimental area was changed each year and the plots were newly established. In 2011, 'Cocodrie' rice, susceptible to sheath blight, was used. The experiment was conducted as a split-plot design with four replications. Plots consisted of seven $5.5-\mathrm{m}$ long rows with a spacing of $20 \mathrm{~cm}$ between rows. The main plots consisted of cover crop treatment with $B$. juncea 'Caliente 199' or nontreated fallow. The subplots were assigned with azoxystrobin application at the rate of $0,0.08$ (half the label rate), and 0.16 (the label rate) $\mathrm{kg}$ active ingredient (a.i.) ha ${ }^{-1}$. In 2012 and 2013, the experiment was conducted as a split-split-plot design with four replications. Two rice cultivars (Cocodrie and 'Presidio', susceptible and tolerant to sheath blight, respectively) were used as a split effect to the main plot effect of cover crop treatment. The sub-subplots were three levels of fungicide application rate, as described above.

Inoculation. Autoclavable polypropylene plastic trays (16 liters in volume) (BEI Art Products, Wayne, NJ) containing rice grain and hull mixture $(1: 2, \mathrm{vol} / \mathrm{vol})$ were filled to one-fifth distilled capacity with distilled water ( $\mathrm{vol} / \mathrm{vol})$, covered with aluminum foil, and autoclaved for $30 \mathrm{~min}$ at $121^{\circ} \mathrm{C}$. The autoclaved grain mixture was kept covered for $24 \mathrm{~h}$ at room temperature (approximately $25^{\circ} \mathrm{C}$ ), then 
autoclaved for a second time and allowed to cool. The doubleautoclaved grain mixture was then inoculated with the isolate TX-RS-1 of $R$. solani AG1-1A that was cultured on one-fifth-strength potato dextrose agar for 4 days. TX-RS- 1 was isolated from a rice plant showing symptoms of sheath blight in a commercial field in Texas. The inoculated grain mixture was covered with aluminum foil and incubated at room temperature for 4 weeks. During the incubation period, the inoculated grain-hull mixture was thoroughly mixed under aseptic conditions in the fume hood every 7 days to allow uniform colonization by $R$. solani mycelium. The colonized grain-hull inoculum was air dried at room temperature for 5 days and stored at room temperature before use. Each plot was inoculated with $R$. solani by manually broadcasting 1.2 liters of $R$. solani-colonized grain inoculum 1 month prior to seeding of $B$. juncea cover crop.

Field plots. At the first-season field trial, B. juncea Caliente 199 was seeded at $5.6 \mathrm{~kg} / \mathrm{ha}$ on 25 March 2011. To determine $B$. juncea aboveground biomass dry weight, a 1-by-1-m quadrant was placed randomly at three different spots in the field and the $B$. juncea biomass in the quadrant area was cut at soil level, oven dried, and weighed. The $B$. juncea plants $(3,451 \mathrm{~kg} / \mathrm{ha})$ were plowed down and incorporated into the soil at the flowering stage on 2 June 2011. Rice was drill seeded at $89.6 \mathrm{~kg} / \mathrm{ha}$ on 14 June 2011 . Rice plots were treated with $\mathrm{N}$ at $63.8 \mathrm{~kg} / \mathrm{ha}$ at post emergence on $20 \mathrm{June}$, and experienced permanent flood on 11 July and panicle differentiation on 4 August in equal installments. Control of weeds and insect pests and irrigation followed the Texas rice production guidelines (26). At the boot stage, plots were sprayed with azoxystrobin (Quadris 2.08 SC; Syngenta, Raleigh, NC) at 0, 0.08 (half of the label rate), and 0.16 (the label rate) $\mathrm{kg}$ a.i./ha using a $\mathrm{CO}_{2}$ pressurized sprayer equipped with a boom of three Tee Jet 8002 nozzles spaced $0.4 \mathrm{~m}$ apart that delivered at 299 liter/ha.

At the second-season field trial, B. juncea Caliente 199 was seeded at $5.6 \mathrm{~kg} / \mathrm{ha}$ on 7 October 2011 and its aboveground biomass $(5,446 \mathrm{~kg} / \mathrm{ha})$ was incorporated into the soil on 3 January 2012 . Rice was drill seeded on 28 March. For the third-season field trial, sowing of B. juncea Caliente 199 was done on 12 October 2012 and its aboveground biomass $(5,974 \mathrm{~kg} / \mathrm{ha})$ was incorporated into the soil on 6 March 2013. Rice was seeded on 13 April. At the second and third seasons, permanent flood in the rice field were established in late May. Fertilizer and insect pest and weed control management were done following the Texas rice production guidelines (26).

Data collection and analysis. Severity of sheath blight was assessed using a scale of 0 to 9 , where $0=$ plants healthy, no symptoms; 1 = restricted dark-brown oval lesions at water line or infection points; 2 = few oval or coalesced lesions, with broad borders on lower sheaths or at infection points, $5 \%$ or less of tissue affected; $3=$ lesions on lower leaf sheaths or at infection points, lesions coalescing, less than $10 \%$ of tissues affected; $4=$ lesions mainly restricted to sheaths on lower third of plant, lowest leaves, or other infection points, lesions discrete or coalescing with narrow redbrown border, 10 to $15 \%$ of leaf and sheath tissues affected; $5=$ lesions mainly restricted to sheaths and leaves of lower half of plants, lesions usually coalescing, with large necrotic centers and narrow red-brown borders, 15 to $25 \%$ of tissues affected; $6=$ lesions usually coalescing and affecting lower two-thirds of sheath area of plant, lesions extending to blades of lower leaves or lower leaves killed by injury to sheath, 25 to $40 \%$ of tissues affected; $7=$ lesions usually coalescing and affecting lower three-fourths of sheath area of plant, lesions extending to leaf blades of lower two-thirds of plant, 40 to $60 \%$ of tissues affected; $8=$ lesions reaching to flag leaf, lower sheaths with coalesced lesions covering most of tissue, lower and middle leaves dead or dying, 60 to $80 \%$ of tissues affected; and $9=$ lesions reaching to flag leaf, lower leaves mostly dead, sheaths dried, culms brown, collapsing, most tillers lodged, over $80 \%$ of tissue affected (4). Disease severity was measured on 21 September 2011, 21 August 2012, and 1 August 2013, approximately 1 week before harvesting. Plots were harvested at maturity using a plot combine each year. Grain moisture contents were determined and rice yields were adjusted to $12 \%$ grain moisture content. The data were subjected to analysis of variance using SAS statistical software (version 9.2; SAS Institute, Cary, NC) to determine treatment effects. Multiple comparisons of significant independent variables were conducted with the Fisher's least significant difference test.

\section{Results}

A $B$. juncea cover crop significantly $(P<0.05)$ reduced sheath blight severity consistently in all 3 years tested (Table 1$)$ and resulted in a significant yield increase in 2013 compared with the fallow control (Table 2). Presidio had significantly less sheath blight severity and produced higher grain yields than Cocodrie in 2012 and 2013 (Table 3). Azoxystrobin application significantly $(P<0.05)$ reduced rice sheath blight severity and increased rice yields in 2012 and 2013

Table 2. Effect of Brassica juncea cover crop on rice sheath blight severity and grain yield in 2011,2012, and $2013^{\mathrm{z}}$

\begin{tabular}{lccccccc}
\hline & \multicolumn{3}{c}{ Disease severity } & & \multicolumn{3}{c}{ Yield (kg/ha) } \\
\cline { 2 - 4 } \cline { 6 - 8 } Treatment & $\mathbf{2 0 1 1}$ & $\mathbf{2 0 1 2}$ & $\mathbf{2 0 1 3}$ & & $\mathbf{2 0 1 1}$ & $\mathbf{2 0 1 2}$ & $\mathbf{2 0 1 3}$ \\
\hline Fallow & $2.3 \mathrm{a}$ & $5.8 \mathrm{a}$ & $4.4 \mathrm{a}$ & & $5,372 \mathrm{a}$ & $7,659 \mathrm{a}$ & $11,269 \mathrm{~b}$ \\
Brassica cover crop & $1.4 \mathrm{~b}$ & $3.8 \mathrm{~b}$ & $3.3 \mathrm{~b}$ & & $6,360 \mathrm{a}$ & $7,940 \mathrm{a}$ & $11,881 \mathrm{a}$
\end{tabular}

${ }^{\mathrm{z}}$ Sheath blight was rated 1 week before harvest on a 0 -to- 9 scale, where $0=$ no disease and $9=$ plants dead and collapsed. Means in the same column with the same letter are not significantly different at $P=0.05$.

Table 3. Effect of rice cultivar on rice sheath blight severity and grain yield in 2012 and $2013^{z}$

\begin{tabular}{llllcc}
\hline & \multicolumn{2}{c}{ Disease severity } & & \multicolumn{2}{c}{ Yield (kg/ha) } \\
\cline { 2 - 3 } \cline { 5 - 6 } Cultivar & $\mathbf{2 0 1 2}$ & $\mathbf{2 0 1 3}$ & & $\mathbf{2 0 1 2}$ & $\mathbf{2 0 1 3}$ \\
\hline Presidio & $3.8 \mathrm{~b}$ & $3.2 \mathrm{~b}$ & & $8,348 \mathrm{a}$ & $11,882 \mathrm{a}$ \\
Cocodrie & $5.8 \mathrm{a}$ & $4.6 \mathrm{a}$ & & $7,251 \mathrm{~b}$ & $11,267 \mathrm{~b}$ \\
\hline
\end{tabular}

${ }^{\mathrm{z}}$ Sheath blight was rated 1 week before harvest on a 0 -to- 9 scale, where $0=$ no disease and $9=$ plants dead and collapsed. Means in the same column with the same letter are not significantly different at $P=0.05$.

Table 1. Analysis of variance ( $P$ value) for the effects of Brassica juncea cover crop, rice cultivar, fungicide application, and their interactions on rice sheath blight severity and grain yield in 2011,2012 , and 2013

\begin{tabular}{|c|c|c|c|c|c|c|c|}
\hline \multirow[b]{2}{*}{ Source } & \multirow[b]{2}{*}{ DF } & \multicolumn{2}{|c|}{$2011^{z}$} & \multicolumn{2}{|c|}{2012} & \multicolumn{2}{|c|}{2013} \\
\hline & & Disease severity & Yield & Disease severity & Yield & Disease severity & Yield \\
\hline Brassica cover crop (BC) & 1 & 0.0305 & 0.119 & 0.0506 & 0.1121 & 0.0126 & 0.0245 \\
\hline Cultivar (CV) & 1 & $\ldots$ & $\ldots$ & 0.0127 & 0.0014 & $<0.0001$ & 0.0080 \\
\hline $\mathrm{BC} \times \mathrm{CV}$ & 1 & $\ldots$ & $\ldots$ & 0.6925 & 0.9947 & 0.8588 & 0.0118 \\
\hline Fungicide $(\mathrm{F})$ & 2 & $<0.001$ & 0.3021 & $<0.0001$ & 0.0009 & $<0.0001$ & 0.0025 \\
\hline $\mathrm{BC} \times \mathrm{F}$ & 2 & 0.1711 & 0.7266 & 0.5218 & 0.8448 & 0.2878 & 0.5985 \\
\hline $\mathrm{CV} \times \mathrm{F}$ & 2 & $\ldots$ & $\ldots$ & 0.5208 & 0.3137 & 0.0042 & 0.8360 \\
\hline $\mathrm{BC} \times \mathrm{CV} \times \mathrm{F}$ & 2 & $\ldots$ & $\ldots$ & 0.0024 & 0.9275 & 0.9857 & 0.7436 \\
\hline
\end{tabular}

${ }^{\mathrm{z}}$ Only one cultivar was evaluated in 2011. 
Table 4. Effect of azoxystrobin application on rice sheath blight severity and grain yield in 2011, 2012, and $2013^{\mathrm{z}}$

\begin{tabular}{lccccccc}
\hline \multirow{2}{*}{$\begin{array}{l}\text { Application } \\
\text { rate (kg a.i. /ha) }\end{array}$} & \multicolumn{3}{c}{ Disease severity $^{\mathrm{z}}$} & & \multicolumn{3}{c}{ Yield (kg/ha) } \\
\cline { 2 - 5 } \cline { 6 - 8 } & $\mathbf{2 0 1 1}$ & $\mathbf{2 0 1 2}$ & $\mathbf{2 0 1 3}$ & & $\mathbf{2 0 1 1}$ & $\mathbf{2 0 1 2}$ & $\mathbf{2 0 1 3}$ \\
\hline 0 & $3.7 \mathrm{a}$ & $6.0 \mathrm{a}$ & $5.9 \mathrm{a}$ & $5,403 \mathrm{a}$ & $7,355 \mathrm{a}$ & $11,170 \mathrm{a}$ \\
0.08 & $1.6 \mathrm{~b}$ & $4.6 \mathrm{~b}$ & $3.1 \mathrm{~b}$ & & $5,919 \mathrm{a}$ & $7,770 \mathrm{~b}$ & $11,595 \mathrm{~b}$ \\
0.16 (label rate) & $1.2 \mathrm{c}$ & $3.7 \mathrm{~b}$ & $2.6 \mathrm{~b}$ & $5,919 \mathrm{a}$ & $8,273 \mathrm{~b}$ & $11,959 \mathrm{~b}$ \\
\hline
\end{tabular}

${ }^{\mathrm{z}}$ Sheath blight was rated 1 week before harvest on a 0 -to- 9 scale, where $0=$ no disease and $9=$ plants dead and collapsed. Means in the same column with the same letter are not significantly different at $P=0.05$.

(Table 1). The increase in azoxystrobin doses from 0.08 to $0.16 \mathrm{~kg}$ a.i./ha did not contribute to an additional disease reduction or yield increase in 2012 and 2013 (Table 4). There were no significant interactions between any treatments (cover crop, cultivar, and fungicide application) consistently in the time evaluated (Table 1).

\section{Discussion}

This is the first report of the field efficacy of $B$. juncea cover crop showing the reduction of the severity of sheath blight in three consecutive years in the field. Consequently, these field evaluations suggest that, when $B$. juncea cover crop is used in combination with a fungicide, the amount of fungicide used can be reduced. This finding is extended from our previous laboratory studies showing that isothiocyanates released from hydrolysis of glucosinolates in B. juncea plant tissue reduced the growth of mycelium of $R$. solani (7).

Our findings on the suppression of rice sheath blight by $B$. juncea cover cropping are in agreement with the previous reports that $B$. juncea cover cropping reduced various soilborne diseases $(9,14-16,19,20,23)$. For example, strawberry (Fragaria $\times$ ananassa Duch.) plots amended with $B$. juncea resulted in the reduction of $R$. solani inoculum by 40 to $56 \%$ and reduced incidence and severity of root disease symptoms (14). Similarly, in the current field study, B. juncea cover crop reduced rice sheath blight severity by 10 to $39 \%$.

$B$. juncea green manure suppressed $R$. solani more effectively in strawberry compared with non-glucosinolate-containing green manure (14). In addition to releasing isothiocynates, incorporation of $B$. juncea plant tissue can benefit crop production by improving overall root health (23). Therefore, sheath blight suppression by Brassica plant tissue is speculated to result from not only immediate biocidal effects of isothiocyanates but also other mechanisms of disease suppression. $R$. solani suppression may be associated with the increase of various beneficial soil microbes as a result of the release of isothiocyanates. More research is needed to elucidate the impact that $B$. juncea tissue has on soil microbes, and to understand how the resulting microbial shifts suppress $R$. solani.

Brassica seed meals have been successfully used for pest management in crop production (18). However, in rice cropping systems, use of $B$. juncea cover crop tends to be more suitable than using Brassica seed meals because $B$. juncea cover cropping is more practical for a large scale of application. In addition, $B$. juncea cover crop may reduce adverse effects such as phytotoxicity. B. juncea plant tissue incorporated into rice fields contains a relatively lower concentration of glucosinolates than $B$. juncea seed meals. Use of Brassica seed meals is frequently associated with phytotoxicity (6).

$B$. juncea cover cropping enables rice farmers to reduce the use of fungicides for management of sheath blight. In the current study, half of manufacturer's label rate (0.08 a.i./ha) of azoxystrobin achieved the same level of sheath blight suppression as the standard label rate (0.16 kg a.i./ha). Even though B. juncea cover cropping did not always result in yield increase, a reduction in sheath blight severity by $B$. juncea cover cropping has the potential to reduce the use of fungicides, increase profit margins, and promote environmental stewardship.

The current study demonstrates that $B$. juncea cover cropping can be added to the rice disease management practices host resistance and fungicide use. With further field efficacy validations, the use of $B$. juncea cover crop can enhance the efficacy of the current integrated pest management program for sustainable control of sheath blight in rice.

\section{Acknowledgments}

This research was supported by the United States Department of Agriculture NIFA SRIPM grant (2010-34103-21156). Additional funding was provided by Texas Rice Research Foundation. We thank G. Liu for technical support and rice field management.

\section{Literature Cited}

1. Brown, P. D., and Morra, M. J. 1996. Hydrolysis products of glucosinolates in Brassica. napus tissues as inhibitors of seed germination. Plant Soil 181: 307-316.

2. Bunemann, E. K., Schwenke, G. D., and Van Zwieten, L. 2006. Impact of agricultural inputs on soil organisms-a review. Aus. J. Soil Res. 44:379-406

3. Groth, D., and Lee, F. 2003. Rice diseases. Pages 413-436 in: Rice Origin, History, Technology, and Production. C. W. Smith and R. H. Dilday, eds John Wiley \& Sons, Hoboken, NJ.

4. Groth, D. E. 2005. Azoxystrobin rate and timing effects on rice sheath blight incidence and severity and rice grain and milling yields. Plant Dis. 89:1171-1174.

5. Gullino, M. L., and Kuijpers, L. A. M. 1994. Social and political implications of managing plant. diseases with restricted fungicides in Europe. Annu. Rev. Phytopathol. 32:559-581.

6. Handiseni, M., Brown, J., Zemetra, R., and Mazzola, M. 2013. Effect of Brassicaceae seed meals with different glucosinolate profiles on Rhizoctonia root rot in wheat. Crop Prot. 48:1-5.

7. Handiseni, M., Zhou, X. G., and Jo, Y. K. 2012. In vitro screening of plant materials as. biofumigants for the management of Rhizoctonia solani in rice. (Abstr.) Phytopathology 102:S6.2.

8. Hao, J. J., Subbarao, K. V., and Koike, S. T. 2003. Effects of broccoli rotation on lettuce. drop caused by Sclerotinia minor and on the sclerotial population in soil. Plant Dis. 87:159-166.

9. Hartz, T. K., Johnstone, P. R., Miyao, E. M., and Davis, R. M. 2005. Mustard cover crops. are ineffective in suppressing soil-borne disease or improving processing tomato yield. HortScience 40:2016-2019.

10. Henderson, D. R., Riga, E., Ramirez, R. A., Wilson, J., and Synder, W. E. 2009. Mustard biofumigation disrupts biological control by Steinernema spp. nematodes in the soil. Biol. Control 48:316-322.

11. Izzo, A., and Mazzola, M. 2006. Differential impact of Brassica spp. seed meal. amendments on fungal populations associated with roots of Malus domesticus from a. replant orchard site. (Abstr.) Phytopathology 96:S53.

12. Kirkegaard, J. A., Sarwar, M., Wong, P. T. W., Mead, A., Howe, G., and Newell, M. 2000. Field studies on the biofumigation of take-all by Brassica break crops. Aust. J. Agric. Res. 51:445-456.

13. Kumar, K. V. K., Reddy, M. S., Kloepper, J. W., Lawrence, K. S., Groth, D. E., and Miller, M. E. 2009. Sheath blight disease of rice (Oryza sativa L.) An overview. Biosci. Biotechnol. Res. Asia 6:465-480.

14. Larkin, R. P., and Griffin, T. S. 2007. Control of soil borne potato disease using. Brassica green manures. Crop Prot. 26:1067-1077.

15. Lazzeri, L., Baruzzi, G., Malaguti, L., and Antoniacci, L. 2003. Replacing methyl. bromide in annual strawberry production with glucosinolatecontaining green manure. crops. Pest Manag. Sci. 59:983-990.

16. Little, S. A., Hocking, P. J., and Greene, R. S. B. 2004. A preliminary study of the role. of cover crops in improving soil fertility and yield for potato production. Commun. Soil Sci. Plant Anal. 35:471-494.

17. Manici, L. M., Lazzeri, L., and Palmieri, S. 1997. In vitro fungitoxic activity of some. glucosinolates and their enzyme-derived products toward plant pathogenic fungi. J. Agric. Food Chem. 45:2768-2773.

18. Mazzola, M., Brown, J., Izzo, A. D., and Cohen, M. F. 2007. Mechanism of action and. efficacy of seed meal-induced pathogen suppression differ in a Brassicaceae species. and time dependent manner. Phytopathology 97:454-460.

19. Motisi, N., Montfort, F., Faloya, V., Lucas, P., and Dore, T. 2009. Growing Brassica. juncea as a cover crop, then incorporating its residues provide complementary control of. Rhizoctonia root rot of sugar beet. Crop Prot. 113:238-245.

20. Njoroge, S. M. C., Riley, M. B., and Keinath, A. P. 2008. Effect of incorporation of. Brassica spp. residues on population densities of soil borne microorganisms and on. damping-off and Fusarium wilt of watermelon. Plant Dis. 92:287-294

21. Olivier, C., Vaughn, S. F., Mizubuti, E. S. G., and Loria, R. 1999. Variation in the allyl. isothiocyanates production within Brassica species and correlation with fungicidal. activity. J. Chem. Ecol. 25:2687-2701.

22. Smolinska, U., and Horbowicz, M. 1999. Fungicidal activity of volatiles from selected. cruciferous plants against resting propagules of soil borne fungal pathogens. Phytopathology 147:119-124.

23. Snapp, S. S., Date, K. U., Kirk, W., O’Neil, K., Kremen, A., and Bird, G. 2007. Root. shoot tissues of Brassica juncea and Cereal secale promote potato health. Plant Soil 294:55-72.

24. Subbarao, K. V., Hubbard, J. C., and Koike, S. T. 1999. Evaluation of broccoli residue. incorporation into field soil for Verticillium wilt control in cauliflower. Plant Dis. 83:124-129.

25. United States Department of Agriculture. 2014. Pages 26-27 in: Crop Production 2013 Summary. National Agricultural Statistics Service, Washington, DC.

26. Way, M. O., McCauley, G. M., Zhou, X. G., Wilson, L. T., and Morace, B. 2013. Texas Rice Production Guidelines. Texas A\&M AgriLife Research and Extension. Service, Beaumont, TX. 